\title{
Navodila za avtorje
}

\section{OBLIKOVANJE BESEDILA}

Prispevki naj bodo v pisavi velikosti 12, opombe v 10.

Citati v tujem jeziku morajo biti opremljeni s prevodom; ob prevodih iz latinščine in grščine naj vedno stoji še izvirnik.

Številka opombe pod črto se v besedilu piše stično; ${ }^{9}$ če je za besedo stično ločilo (pika, ${ }^{9}$ vejica, dvopičje, zaklepaj), ${ }^{9}$ stoji številka za ločilom in ne pred njim. ${ }^{9}$

Pri dobesednem navajanju se uporabljajo »dvojni srednji«, pri navajanju znotraj navedka 'enojni zgornji' narekovaji.

Ema je zaničljivo vprašala: „Kakšna 'obljuba'?»

Z narekovaji so opremljeni krajši citati, vključeni v besedilo. Daljši citati so »v bloku«, brez narekovajev ter ločeni od ostalega besedila $\mathrm{z}$ vrstico presledka, na levi pa od roba strani z ukazom »Povečaj za$\operatorname{mik} \lll$ ( $\overline{\underline{\underline{\underline{B}}}}$ ).

\section{UPORABA KURZIVE}

Brez kurzive so daljši navedki v tujem jeziku označeni drugače, torej $\mathrm{z}$ narekovaji, ali postavljeni ločeno.

V kurzivi so posamezne besede ali fraze v tujem jeziku; če jim sledi prevod, je v oklepaju ali narekovajih brez kurzive.

Namesto pécher (grešiti) je uporabila pêcher (ribariti).

V kurzivi navajamo tudi naslove knjig in revij.

\section{NAVAJANJE V OPOMBAH}

Revija uporablja čikaški standard za citiranje (CMOS 17).

Značilnost tega sloga je navajanje naslova fizične bibliografske enote, torej knjige oziroma revije, $v$ kurzivi, medtem ko so naslovi sestavnih delov, torej poglavij ali člankov v knjigi, reviji ali zborniku, »v narekovajih«. 
Literaturo citiramo z navajanjem avtorja in (po potrebi skrajšanega) naslova $v$ opombah. $\mathrm{V}$ sprotnih opombah zadostuje avtorjev priimek $s$ po potrebi skrajšanim ${ }^{1}$ naslovom dela in stran, na katero se opomba sklicuje:

Kastelic, Umreti ni mogla stara Sibila, 66.

Škiljan, "Antika pred izginotjem», 166.

Simoniti, »Über die Responsio«, $55 .^{2}$

Pomoč pri kompleksnejših bibliografskih enotah je na voljo v omenjenem priročniku ${ }^{3}$ in na spletu.

\section{NAVAJANJE V KONČNI BIBLIOGRAFIJI}

a) Knjiga

Kastelic, Jože. Umreti ni mogla stara Sibila: Prešeren in antika. Ljubljana: Modrijan, 2000.

Če so avtorji več kot trije, za prvim v opombi stoji kratica et al.; v končni bibliografiji so navedeni vsi.

- urednik, prevajalec, sestavljalec namesto avtorja

Kokole, Metoda, Barbara Murovec, Marjeta Šašel Kos in Michael Talbot, ur. Mediterranean Myths from Classical Antiquity to the Eighteenth Century. Ljubljana: ZRC, 2006.

1 Skrajšujemo zlasti naslove, ki imajo več kot pet besed ter se v opombah navajajo večkrat; ko se $\mathrm{v}$ opombi pojavi prvič, naslov navedemo v celoti. V skrajšanem naslovu ohranimo začetne ali ključne besede izvirnega naslova. Navajamo ga bodisi v kurzivi bodisi v narekovajih, prav kot izvirni naslov. - V angleščini se v skrajšanem naslovu izpušča člen $(a$, the). Pri jezikih, ki imajo sklone, se ohranjajo členi, ki vplivajo na ključno besedo v skrajšanem naslovu.

2 Če je skrajšani citat vrinjen v stavek, ga zaključimo z vejico, npr. Simoniti, „Über die Responsio«, 55, omenja tudi ...

3 University of Chicago Press, The Chicago Manual of Style, 17. izd. (Chicago: University of Chicago Press, 2017). 
- urednik, prevajalec, sestavljalec poleg avtorja

Finley, Moses I. Antična in moderna demokracija. Prevod Borut Cajnko. Ljubljana: Krtina, 1999.

- poglavje ali podoben (naslovljen) del knjige

Škiljan, Dubravko. »Antika pred izginotjem«. V: Antika za tretje tisočletje, ur. Maja Sunčič in Brane Senegačnik, 165-70. Ljubljana: ZRC, 2004.

b) Članek v reviji

Simoniti, Primož. "Über die Responsio contra Apologiam Melanchthonis, ein wiedergefundenes Werk des Augustiner-Eremiten Bartholomaeus Arnoldi von Usingen«. Augustiniana 25 (1975): $48-57$.

\section{LATINSKI IN GRŠKI AVTORJI}

Številke knjig, odstavkov, vrstic ipd. zapisujemo $\mathrm{z}$ arabskimi števkami, ločenimi s pikami brez presledka; pri redkih avtorjih je v rabi drugačen sistem (denimo črke).

Ovidij, Umetnost ljubezni 1.59 .

Aristotel, Metafizika 3.2.996b5-8; Platon, Država 36oe-361b.

Imena klasičnih avtorjev in naslove del v glavnem besedilu navajamo v neokrajšani poslovenjeni obliki ali v latinski obliki, če je ta bolje prepoznavna (npr. Ovidij, Amores). Če gre za avtorja enega samega dela, lahko naslov izpustimo (npr. Tukidid, Livij). Manj pomembne navedbe mest, zlasti v opombah, imajo lahko okrajšano obliko.

Thuc. 2.40.2-3

Pindar, Isthm. 7.43-45.

Kritično izdajo v bibliografiji navajamo pod imenom urednika:

Morton Braund, Susanna, izd. Juvenal and Persius. Loeb Classical

Library 91. Cambridge, MA: Harvard University Press, 2004. 